\title{
Augustínov postoj v kauze prenasledovania donatistov: Dve otvorené otázky
}

\author{
Andrea Blaščíková \\ Univerzita Konštantína Filozofa v Nitre, SK
}

BLAŠČÍKOVÁ, A.: Augustine's Attitude in the Case of Donatists'
Persecution: Two Open Questions.
Philosophica Critica, vol. 2, 2016, no. 1, ISSN 1339-8970, pp. 33-47

The contribution reopens a repeatedly interpreted topic of Augustine's attitude in the case of Donatists' persecution, namely under the specific viewpoint of two nowadays evoked questions. In the first part, it clarifies that beyond Augustine's agreement with using of violent methods when the non-violent failed that was the positive experience in condition that coercion, pursuing the truth, helped donatists to return to the unity and so to the way of salvation. In the second part, it approaches to two open questions of the current discussion about Augustine's attitude. Firstly, it asks for the reasons Augustine's theory is not irreconcilable with the whole of his state concept. This reasons represent Augustine's tendency to outline an earthly city to heavenly city, which is the specific role of the Christian monarchs and at the same time Augustine's conception of the human nature, according to which a man without the divine (and through the participation also the human) support is able only of evil. Secondly, it asks if the Augustine's attitude is in accordance with the current liberal concept of freedom. It summarizes that for liberal comprehension, accentuating freedom nearly as absolute value, is Augustine's attitude, grasping freedom in function of the goal, unacceptable.

Key words: Augustine - Donatists - Coercion - Freedom

\section{Úvod}

Prenasledovanie donatistov časovo spadá do obdobia po vydaní tolerančného ediktu (r. 313) cisárom Konštantínom Vel'kým po približne šieste storočie, kedy sa t'ažisko pozornosti cirkvi presunulo na problémy súvisiace so šíriacim sa islamom. V našom príspevku si položíme otázku, akými argumentmi zdôvodnil 
vplyvný biskup - Augustín Aurélius (354-430) - svoje súhlasné stanovisko s použitím silových prostriedkov štátu proti donatistom. Opierat' sa pritom budeme o vybrané Augustínove diela, v ktorých vysvetl'uje zmenu svojho postoja. Následne zameriame pozornost' na súčasnú diskusiu o tejto Augustínovej argumentácii. Konkrétne sa zameriame na problém zlučitel'nosti obhajoby násilia voči donatistom s Augustínovou koncepciou štátu a na problém prijatel'nosti Augustínovho postoja k prenasledovaniu donatistov v kontexte liberálneho poňatia slobody, prezentovaného v našom článku názorom J. S. Milla.

\section{Donatistická schizma v africkej cirkvi}

Donatistami sa nazývajú severoafrickí krest’ania, ktorí sa postavili proti návratu do cirkvi tých klerikov, ktorí počas Diokleciánovho prenasledovania (r. 303-305) odovzdali svetským úradom na zničenie opisy Písma. Týmto činom daní klerici verejne zapreli Krista i Cirkev, a teda podl'a donatistov odpadli od viery, stratili moc platne vysluhovat' sviatosti (Bonner 2008, 201) a cirkev by ich mala vylúčit' zo svojho stredu spolu s inými preukázanými verejnými hriešnikmi. Donatisti vo svojom uvažovaní vychádzali z doslovného prevzatia starozákonného konceptu „obradného poškvrnenia človeka pri kontakte s mŕtvolou (contaminare). Kontakt s hriešnikom, o ktorom sa vie, že je taký, prináša morálne poškvrnenie tomu, kto sa s ním stýka - hoci len pri bohoslužbe, a pretože sa Katolícka cirkev neoddelila od biskupa Caeciliana, ktorého donatisti pokladali za apostatu, je celá Katolícka cirkev, s výnimkou ich (donatistického) afrického spoločenstva, kontaminovaná jeho hriechom a hriechmi iných známych hriešnikov, a preto sú všetky v nej vysluhované sviatosti neplatné" (Lichner 2014, 139). ${ }^{1}$ Radikálna skupina donatistov sa oddelila od katolíkov a stala sa schizmatickou sektou chápajúcou samu seba ako jedinú ozajstnú dedičku predkonštantínovského krest'anstva, t.j. krest'anstva pred vydaním Milánskeho ediktu, zrovnoprávňujúceho náboženstvá v Ríši. Následné prenasledovanie katolíkmi posilnilo ich presvedčenie o pravosti vlastnej cirkvi, lebo im poskytovalo prepojenie s krest’anmi prenasledovanými v minulosti (Garbarino 2011, 49-50), čo však neznamená, že by samotní katolíci tiež neboli prenasledovaní donatistami. Najmä radikálna skupina tzv. circumcellionov (circumcelliones), ktorá sa zrejme vymkla aj z donatistického vedenia, sa potulovala po africkom vidieku, jej členovia rabovali a neštítili sa ani vraždenia katolíkov (Andoková 2013, 62).

\footnotetext{
${ }^{1}$ Pozadie tohto konfliktu spoluutvárali aj sociálno-politické dôvody, ked'že na stranu donatistov sa pridávali najmä chudobní obyvatelia vidieka, čiže pôvodné obyvatel'stvo, pre ktoré bol katolicizmus formou krest’anstva prineseného do Afriky za podpory cisára, bohatých vlastníkov pôdy a armády (Andoková 2013, 47).
} 
Donatizmus sa tak stal zdrojom rozdelenia a verejným problémom v africkej časti Impéria. Boli vydané viaceré politické rozhodnutia proti nim, ale ked’že nepokoje neutíchali, dokonca sa následkom pôsobenia circumcellionov zhoršovali, od r. 405 sa protidonatistickým dekrétom cisára Honoria perzekúcie rozšírili na všetkých donatistov bez ohl'adu na to, či vyvolávali nepokoje alebo nie. Konferencia v Kartágu (r. 411) sa považuje za definitívne vít'azstvo katolíckej strany v spore (Smither 2006, 4-5).

\section{Augustínov postoj v kauze prenasledovania donatistov}

Augustín ako biskup v africkom meste Hippo, podobne ako iní africkí biskupi, bol nútený zaujat' voči donatistom postoj. Spočiatku (v rokoch 392-402) sa snažil urovnat' konflikt diplomatickou cestou, teda argumentmi a slovným presviedčaním, prejavujúc záujem o skutočné riešenie. Vo svojej korešpondencii i v dielach neprestáva uvádzat' teologické argumenty, pre ktoré sa donatisti mýlia vo svojich presvedčeniach. Predovšetkým nástojí na tolerancii (trpezlivosti) voči slabým údom Cirkvi. Odvoláva sa pritom na biblické podobenstvo o pšenici a kúkoli, ktoré musia spolu rást’ až do žatvy, teda až do konca časov, kedy Kristus príde oddelit’ dobrých od zlých (Augustinus, De patientia 9, 8). ${ }^{2}$ Rozpracúva náuku o platnosti krstu, ktorý negarantuje bezúhonný vysluhovatel', ale Kristus (Augustinus, Contra litt. Petil. 3, 33). Hlása, že bez krest’anskej lásky ani platne udelený krst nič neosoží a „láska chýba tam, kde došlo k porušeniu jednoty“ (Karfíková 2011, 95), teda k schizme, ktorej sa dopustili donatisti. Pokusy o dialogickú cestu sa však ukázali ako neúčinné, predovšetkým pre neochotu donatistov zúčastňovat' sa ich.

Augustínov obrat v postoji voči donatistom nebol zapríčinený len násilím donatistov a ich neochotou komunikovat'. V jeho odpovedi donatistickému učencovi Cresconiovi, či v jeho polemikách s donatistickými biskupmi Parmenianom a Petilianom možno sledovat' i Augustínovo teologické zdôvodnenie použitia násilia. Dôvody zmeny názoru predkladá v liste Vincentiovi z roku 408. Ako rozhodujúci tu Augustín uvádza nečakane pozitívny účinok donucovania, ktorý nenaplnil obavy z vytvorenia falošných/zdanlivých katolíkov (fictos catholicos). ${ }^{3}$ Augustín aj ostatní africkí biskupi totiž pozorovali, že ked' sa l'udia zo strachu pred sankciami vyplývajúcimi z cisárskych výnosov obrátili, neostali v rozdvojenosti srdca a vonkajšieho vyznania, ale nakoniec vzdávali vd’aky za to, že pod tlakom našli pravú cirkev. Augustín v liste Vincentiovi rekapituluje vyjadrenia samotných konverti-

\footnotetext{
${ }^{2}$ Augustínovmu ekleziálnemu chápaniu trpezlivosti (tolerancie) sa podrobne venuje vo svojej monografii M. Lichner (Lichner 2014).

3 V liste Bonifácovi uvádza ten istý argument v znení, že každý by mal byt' slobodný sledovat' katolícku pravdu bez toho, aby bol k tomu vnútorne donucovaný obavami (z trestov), aby sme nemali "falsos et simulatores catholicos" (Augustinus, Ep. 185, 25).
} 
tov, ktorí sa vyznávajú, že boli od obrátenia zdržiavaní strachom z postihov zo strany donatistov, iní v zotrvačnosti uväznení nie ret'azami pravdy, ale putami zarytého zvyku, d'alší otupení pohodlím, v ktorom žili, a leniví študovat' katolícku pravdu, niektorí oklamaní rečami o katolíkoch, či lacno presvedčení o tom, že je jedno, či je človek katolík alebo donatista, ak je krest’anom (Augustinus, Ep. 93,17). ${ }^{4}$ Všetci títo podl'a ich vlastných slov nakoniec profitovali zo zákonov trestajúcich príslušnost' k donatizmu. Augustínova logika ospravedlnenia donucovania vo veciach náboženského presvedčenia heretikov je teda postavená na tom, že opatrenia proti nim im vlastne majú pomôct'; majú ich primät' k zamysleniu, či útrapy znášajú pre spravodlivost', alebo či náhodou netrpia pre svoju neprávost'. Rôzne formy prenasledovania ${ }^{5}$ sa osvedčili ako prostriedok, bez ktorého by sa človek neprepracoval k opusteniu pôvodných stanovísk vo veci viery. Augustín nepochybuje o tom, že vyučovanie musí byt' vždy na prvom mieste, ale netreba zanedbávat' ani tých, ktorí ho nepochopia:

„Kto by pochyboval o tom, že je lepšie privádzat' k Božiemu kultu l'udí poučením, než ich tlačit' strachom z trestu alebo bolest'ou; ale z toho dôvodu, že existujú l'udia prístupní pravde, netreba zanedbávat' tých, ktorí takými nie sú. Skúsenost' nám dosvedčila a dosvedčuje stále, že strach a bolest' boli pre mnohých prospešné, aby sa nechali poučit' a aby praktizovali to, čo sa už naučili“ (Augustinus, Ep. 185, 21). ${ }^{6}$

Človek je a ostáva otrokom svojich zvykov, pokial' nejaký vonkajší tlak nespôsobí, že je nútený prehíbit' svoje ukotvenie v názoroch. Tie však, ked’že sú mylné,

4 "Quam multi enim, quod certo scimus, iam volebant esse catholici, manifestissima veritate commoti, et offensionem suorum reverendo, quotidie differebant! Quam multos non veritas, in qua numquam praesumpsistis, sed obduratae consuetudinis grave vinculum colligabat, ut in eis compleretur divina illa sententia: Verbis non emendabitur servus durus; si enim et intellexerit, non obediet [Prov 29, 19]! Quam multi propterea putabant veram Ecclesiam esse partem Donati, quia eos ad cognoscendam catholicam veritatem securitas torpidos, fastidiosos, pigrosque faciebat! Quam multis aditum intrandi obserabant rumores maledicorum, qui nescio quid aliud nos in altare Dei ponere iactitabant! Quam multi nihil interesse credentes in qua quisque parte christianus sit, ideo permanebant in parte Donati, quia ibi nati erant, et eos inde discedere atque ad Catholicam nemo transire cogebat!" (Augustinus, Ep. 93, 17).

${ }^{5}$ Augustín bol proti trestu smrti pre donatistov i proti mučeniu; pripúšt'al pokuty, bičovanie, konfiškáciu a exil, žiadal však miernost' a zhovievavost' v trestaní, najmä ak ide o zblúdené ovečky (porov. Augustinus, Ep. 93, 10; 185, 26).

${ }^{6}$ „Melius essa quidem quis dubitaverit? ad Deum colendum doctrina homines duci, quam poenae timore vel dolore compelli: sed non quia isti meliores sunt, ideo illi qui tales non sunt, neglegendi sunt. Multis enim profuit (quod experimentis probavimus et probamus) prius timore vel dolore cogi, ut postea possent doceri, aut quod iam verbis didicerant, opere sectari“ (Augustinus, Ep. 185, 21). 
neobstoja, a človeka to privedie k vnútornému obráteniu. Preto, ako hovorí $\mathrm{Au}$ gustín, vyučovanie a užitočná obava idú ruka v ruke, „nielen svetlo pravdy zaháňa temnoty omylu, ale tiež sila strachu láme ret’aze zlého zvyku“ (Augustinus, Ep. 93,3). ${ }^{7}$ Pre Augustína teda nemajú donucovanie a tresty slúžit' na nič iné než na nápravu, ako trpký liek pomáha chorým dostat' sa zo zovretia choroby.

Dôležitou podmienkou je to, že donucovanie trestom nesmie vychádzat' z inštinktu pomsty, ale z krest’anskej lásky. Augustín pripomína Marcellinovi: „Chop sa, krest’anský sudca, povinnosti zbožného otca, rozhorli sa na neprávost' tak, že budeš pamätlivý l'udskosti a budeš na ňu dbat', že nebudeš uplatňovat' túžbu po pomste voči ukrutnostiam, ktorých sa hriešnici dopustili, ale že v sebe nájdeš vôl'u hojit' zranenia, ktoré si spôsobili“ (Augustinus, Ep. 133, 2). ${ }^{8}$ Samotný postoj vonkajšieho donucovania teda nesmie protirečit' príkazu a výzve lásky a nie je ani v rozpore s krest'anskou trpezlivost'ou. Podl'a Spanneuta chápe Augustín trpezlivé nenásilie ako dispozíciu srdca, ktorú by rušila skôr túžba po pomste, než vonkajší prejav násilia, vnútorne zakorenený v láske (Spanneut 1990, 82-84). Trestanie má priviest' hriešnika $\mathrm{k}$ spamätaniu sa, teda de facto $\mathrm{k}$ dobru, a práve to ho činí legitímnym. V žiadnom prípade by sa za oprávnené nemohlo považovat' donucovanie, ktoré by privádzalo $\mathrm{k}$ zlu9 , alebo by vychádzalo $\mathrm{z}$ nenávisti či žiadostivosti. ${ }^{10}$ To samozrejme kladie vysoké nároky na vnútorné zmýšlanie katolíkov, aby sa držali kritéria krest’anskej lásky:

„Avšak vo všetkom a všade má človek sledovat’ spôsob najlepšie prispôsobený l'udskosti, najviac vyhovujúci láske; nech sa nevytrhne všetko, čo

7 ,[...] non solum tenebras erroris lux veritatis expellat, verum etiam malae consuetudinis vincula vis timoris abrumpat" (Augustinus, Ep. 93, 3).

8 „Imple, christiane iudex, pii patris officium; sic succense iniquitati, ut consulere humanitati memineris: nec in peccatorum atrocitatibus exerceas ulciscendi libidinem; sed peccatorum vulneribus curandi adhibeas voluntatem" (Augustinus, Ep. 133, 2). Slovenský preklad je upravený podl'a českého prekladu R. Hošeka (Augustinus 2000, s. 307).

9 „Verím, že teraz vidíte, že sa netreba starat’ len o nátlak, ale treba zvažovat’ aj to, k čomu je človek prinútený, či je to dobro alebo zlo“ („Vides itaque iam, ut opinor, non esse considerandum quod quisque cogitur, sed quale sit illud quo cogitur, utrum bonum an malum") (Augustinus, Ep. 93, 16).

10 „Odsudzujeme každého, pre koho by sa cisárske zákony stali príležitost'ou ukájania nenávisti voči vám, namiesto láskyplnej práce na vašom prinavrátení. [...] odsudzujeme každého, pre koho sa tieto zákony, spísané král'mi, služobníkmi Krista, proti bezbožnej schizme, stali príležitost'ou pre chamtenie po tom, čo vám patrí. Odsudzujeme každého, kto berie v chtivom a nie v spravodlivom zmýšl’aní [...]“ „Quicumque vos ex occasione legis huius imperialis, non dilectione corrigendi, sed inimicandi odio persequitur, displicet nobis. [...]sed tamen quisquis ex occasione huius legis, quam reges terrae Christo servientes, ad emendandam vestram impietatem promulgaverunt, res proprias vestras cupide appetit, displicet nobis. [...]“ (Augustinus, Ep. 93, 50). 
človek má moc vytrhnút'; a ked' sa vytrháva, nech sa nestratí zo zretel'a láska; a ked' sa zdržuje vytrhávania, nech sa prejaví vel'ká zhovievavost'. Konečne, vo veciach, ktoré nie sú podriadené žiadnemu Božiemu alebo l'udskému zákonu, nech sa prihliada vždy na počestnost' a rozvážnost'" (Augustinus, Contra Cresc. 3, 57). ${ }^{11}$

Spanneut $(1990,101)$ sa vyjadril, že táto teória, dávajúca absolútny primát úmyslu, sa dá dat' do súvisu so známym Augustínovým výrokom: „Miluj a rob, čo chceš“ (Dilige et quod vis fac) (Augustinus, In Ep. Io. tr. VII, 8). Nátlak sa stal Augustí-novou argumentáciou súčast’ou božského plánu: „stal sa prvkom stvoritel'skej a vykupitel'skej vôle, schopnej ontologicky ho pretransformovat"“ (Spanneut 1990, 101).

\section{Problém zlučitel'nosti Augustínovho príklonu k štátnemu donucovaniu donatistov $s$ jeho sekulárnym poňatím štátu}

Optát z Milevu, biskup a bojovník proti donatistom, zachytil v svojich spisoch chýrnu vetu Donata z Kartága: „Quid est imperatori cum ecclesia?“ („Čo majú spoločné cisár a cirkev?) (Optatus, Adv. Parm. 3, 3). Táto otázka vznesená donatistami ostala problémom aj pre súčasných interpretov Augustína. Prečo sa cirkev, majúca za ciel' spásu človeka, opiera o pomoc štátu, ked’ nezvláda svoju vnútornú opozíciu? Teoreticky Augustín obmedzuje kompetencie štátu na časné záležitosti. V diele O Božej obci (De civitate Dei) rozvíja svoju koncepciu, podl'a ktorej žiaden štát, ani ten, ktorý by riadili krest’anskí panovníci, nie je stotožnitel'ný s Božou obcou vyvolených, podobne ako s ňou nie je zamenitel'né spoločenstvo cirkvi. Až druhý príchod Krista oddelí zrno od pliev, Božiu obec vyvolených od pozemskej obce. Pozemská obec sa zaoberá časnými, materiálnymi a svetskými záležitost'ami, kým nebeská obec večnými, duchovnými a nebeskými vecami (Augustinus, De civ. Dei 14,28). V Augustínovom poňatí preto niet dôvodu pre to, aby štát prekračoval svoje kompetencie, ktoré sú vymedzené sekulárne, teda starost'ou o zabezpečenie dobra pozemského života.

S touto víziou je podl'a R. A. Markusa Augustínov postoj v kauze donatistov $\mathrm{v}$ rozpore, dokonca jeho odklon od inak sekulárneho poňatia štátu považuje za nie celkom doriešené napätie. Uvádza, i ked’ d'alej nešpecifikuje, že ak Augustín

\footnotetext{
11 „Sed in omnibus tenendus est modus aptus humanitati, congruus caritati, ut nec totum quod potestatis est exeratur et in eo quod exeritur dilectio non amittatur, in eo autem quod non exeritur mansuetudo monstretur. Ubi vero nulla ex divinis humanisve legibus potestas conceditur, nihil improbe atque imprudenter audeatur" (Augustinus, Contra Cresc. 3, 57).
} 
po dlhom zdráhaní podporil použitie sily proti heretikom a schizmatikom, urobil tak skôr na naliehanie a nátlak ostatných biskupov (Markus 2002, 467). S Markusom sa dá sčasti súhlasit' v tom, že nie teoretické dôvody, ale prax (donatisti sa pod tlakom perzekúcií obracajú skutočne, nie iba navonok) viedla Augustína k príklonu k metódam donucovania. Ako už bolo povedané, prípadné použitie násilia v praxi neprotirečí vnútornej dispozícii znášat' či tolerovat' všetko, lebo je pre vinníka šancou príst' k rozumu a pre krest’ana v závislosti od okolností povinnost'ou krest’anskej lásky. Situácia praxe môže byt' o to komplikovanejšia, že ide o oblast' náboženstva (religio), ktorá po istej stránke spadá i pod kompetenciu štátu, nielen Cirkvi. Ak k tomu pridáme nepokoje a porušenia verejného poriadku, ktoré nastali predovšetkým v radoch extrémistov, náboženské záležitosti sa stali problémom aj pre štát.

M. Vašek v tejto súvislosti upozorňuje na to, že medzi náboženstvom a štátom existuje u Augustína i iné prepojenie, ktorým je spravodlivost'. Spravodlivost' sa realizuje na viacerých úrovniach. Spravodlivý človek je predovšetkým vo všetkom podriadený pravému Bohu, vládne v ňom duch nad telom, rozum nad vášňami. Štát a jeho zákony tiež možno nazvat' spravodlivými, len ak podliehajú večnému zákonu (Vašek 2007, 155). Možno preto povedat', že vzhl'adom na cnost' spravodlivosti nie je politická doména úplne autonómnou oblast'ou, nezávislou od posledných ciel'ov, ako tvrdí J. R. Bowlin. Ak by totiž vládcovia zabezpečovali dobrá časného života bez ohl'adu na posledné ciele, mohli by tým slúžit' nie spravodlivému Božiemu pokoju, ale zvrátenému pokoju milovníkov moci a vlastného prospechu (ciele od Boha odvrátenej pozemskej obce). Podl'a Bowlina spájal Augustín panovanie krest'anských vladárov s nádejou, že bude zabezpečený časný pokoj. Ked'že obec, ktorá nevzdáva náležitú úctu pravému Bohu, nemôže očakávat' realizáciu spravodlivosti, nezdá sa podl'a neho nekonzistentné, ak bude proti náboženským odporcom použité primerané štátne donucovanie (Bowlin 1997, 59$60)$.

Dá sa teda povedat', že hoci Augustín nestotožňuje Božiu obec vyvolených so žiadnou pozemskou realitou a vládou, predsa úsilie krest'anských panovníkov žit' krest’anské hodnoty a chránit' záujmy cirkvi, ktoré dejinne nastalo, považuje za chvályhodné a bohumilé (Augustinus, De civ. Dei 5, 24-26). V tomto duchu pri interpretácii uvažoval aj P. Brown. Podl'a neho Augustínovo presvedčenie o dejinách spočíva na stotožnení vlády krest'anských panovníkov s prorokmi predpovedanou pravdou, že cirkev sa mala rozšírit' pomedzi všetky národy, že pozemskí králi by mali slúžit' Kristovi v strachu a chvení a že bohovia národov by mali byt' vykorenení zo zemského povrchu (Brown 1964, 110; Augustinus, Ep. 185,1). Cisári teda nielenže môžu, ale i majú trestat' bezbožnost' (pohanov, heretikov, schizmatikov), aby tým naplnili to, čo sa na nich zo starozákonných proroctiev vzt'ahuje. Božiu obec treba predsa budovat', čo zahŕňa i napomáhanie zranenej l'udskej slobode, aby smerovala k Dobru (Spanneut 1990, 113). K názoru sa prikláňa aj J. 
Rohr, podl'a ktorého mal Augustín sklon absorbovat' prirodzené do nadprirodzeného, dejiny vzt'ahoval k prozretel'nosti, prirodzenost' $\mathrm{k}$ milosti, rozum $\mathrm{k}$ viere, politiku k náboženstvu, a to čo do hodnoty a miesta v spirituálnom poriadku, nie čo do inštitúcií. Táto tendencia je evidentná, ked’ Augustín hovorí o vládnutí krest’anských panovníkov ako o službe Bohu, ktorá je použitá pre šírenie pravého náboženstva (Rohr 1967, 69-70).

Iného spoločného menovatel'a problému zdanlivej inkonzistencie Augustínovej nedôvery voči štátu ako nositel’ovi náboženského poslania na jednej strane a predstavy krest'anského vladára ako výkonného orgánu násilia uplatňovaného cirkvou v záujme náboženskej jednoty na druhej strane označila L. Karfíková. Týmto spoločným menovatel'om či spoločným koreňom je podl'a nej Augustínova náuka o pokazenej l'udskej prirodzenosti, schopnej bez nezaslúženej Božej pomoci len zla (Karfíková 2011, 121). To by zodpovedalo postupne sa formujúcemu protipelagiánskemu presvedčeniu Augustína o nepomere l’udského smerovania k spáse prostredníctvom skutkov a Božej všemohúcnosti. Prílišná koncentrácia na skutky slobodného rozhodovania môže akoby zastriet' pohl'ad na vyšší rozmer úmyslu a sily všemohúceho Boha, ktorého nepredvídatel'né zvraty v dejinách individuálnej duše aj spásy l'udstva svedčia o tom, že individuálny skutok slobodného rozhodovania (liberum arbitrium) „je mysteriózne inkorporovaný do poriadku, ktorý spočíva mimo oblast' sebaurčovania“" (Brown 1964, 111). Augustín sa často odvoláva na Šavlovo náhle oslepnutie a zrazenie na zem na ceste do Damasku (Sk 9, 3-7), plodom ktorého bola jeho nepredvídatel'ná a rozumovo nepochopitel'ná konverzia (Augustinus, Ep. 93, 5; 185, 22; 173, 3). ${ }^{12}$ Od tohto uvedomenia si Božieho pôsobenia na l'udskú vôl'u, ktoré donucuje bez toho, aby odstraňovalo slobodu rozhodovania, nie je d'aleko k ospravedlneniu násilia a nátlakových opatrení zo strany štátu (Karfíková 2011,101).

Ak by sme na základe predostretej argumentácie prijali, že Augustínova koncepcia štátu, ktorý nemá náboženské poslanie, nie je nekonzistentná s jeho súhlasom s násilím krest’anských panovníkov vo veci donatistov, otvára sa druhý problém, ktorým je nezlučitel'nost' tejto pozície so súčasným chápaním slobody.

\section{Problém prijatel'nosti Augustínovho postoja k donatistom v kontexte liberálneho chápania slobody}

Ak prijmeme pádnu tézu, že najhlbším teologickým dôvodom Augustínovho pristúpenia k istým (limitovaným) formám násilia voči donatistom je jeho presved-

12 Ako iný, často opakovaný motív Božieho donucovania uvádza Augustín podobenstvo o vel'kej večeri $(L k 14,12-24)$, konkrétne čast' verša 23: „donút' vojst' všetkých“ (porov. Augustinus, Ep. 93, 5; 185, 24; 173, 10). 
čenie, že slobodná vôl'a je schopná dobra, len ak je dvíhaná Božou milost'ou, tak v horizonte pastoračného úsilia cirkvi sa zdajú byt' namieste rôzne analógie tohto Božieho pôsobenia na vôl'u, či už presviedčanie, vysvetl'ovanie, alebo i väčší nátlak, ktorého ciel'om v súlade s Augustínom nie je prinútit' $\mathrm{k}$ viere, ale prinútit' vôl'u k serióznemu zamysleniu sa. Túto skutočnost' vystihuje úryvok z Augustínovej druhej knihy Proti listom Petiliána (Contra litteras Petiliani):

\begin{abstract}
„Ako môže [Boh] prit’ahovat' [k Synovi], ak každému dovol'uje zvolit' si to, čo chce? Je isté, že Boh prit’ahuje a že človek ostáva slobodný, ale máloktorý krest’an dokáže uchopit' toto tajomstvo. Rovnako ako Otec prit’ahuje k svojmu Synovi l'udí, ktorých obdaroval slobodným rozho-dovaním, tak i zákony nás nezbavujú tohto slobodného rozhodovania, hoci sa nám vnucujú pod hrozbou trestu. Utrpenie, ktoré človek zakusuje, ho nabáda pýtat' sa seba, prečo trpí: ak si uvedomí, že trpí pre spravodlivost', prejaví cnost', ked' sa rozhodne trpiet' pre spravodlivost'. Ak rozpozná, že trpí pre nespravodlivost' a nadobudne presvedčenie, že tieto utrpenia a bolesti by preňho boli úplne bez úžitku, prevedie svoju vôl'u k dobru a razom sa očistí od sterilného utrpenia a samotnej nespravodlivosti, ktorej sa tisíckrát viac treba obávat', než najkrutejších útrap. Ked' kniežatá kladú proti vám zákony, bud'te si istí, že predovšetkým chcú, aby ste začali uvažovat' o príčine vašich utrpení: ak chcú, aby ste trpeli pre spravodlivost', stanú sa vašimi prenasledovatel'mi a vy ste št'astní, že trpíte pre spravodlivost', pretože tým budete vlastnit’ nebeské král'ovstvo (Mt 5,10; 1 Pt 2,20). Ale ak vás nechávajú trpiet' kvôli nespravodlivosti vašej schizmy, sú pre vás skutočnými nástrojmi vašej konverzie a vy, stanúc sa smutne podobnými tým, ktorí ako vinníci mnohých zločinov znášajú zákonný trest, sa stávate nešt’astnými pre tento život i pre život budúci. Teda nikto vás nezbavuje vášho slobod-ného rozhodovania. Uvažujte z vašej strany vážne o vol'be, ktorú máte učinit': chcete žit' v pokoji po úprimnom obrátení alebo, pretrvávajúc vo vašej zvrátenosti, sa chcete pod falošným menom martýrov vystavit' skutočným mukám?" (Contra litt. Petil. 2,185).13
\end{abstract}

13 „Quomodo enim attrahit, si dimittit ut quis quod voluerit eligat? Et tamen utrumque verum est: sed intellectu hoc penetrare pauci valent. Sicut ergo fieri potest ut quos in libero dimisit arbitrio, attrahat tamen Pater ad Filium; sic fieri potest ut ea quae legum coercitionibus admonentur, non auferant liberum arbitrium. Quidquid enim homo durum et molestum patitur, admonetur ut cogitet quare patiatur; ut si pro iustitia se pati perspexerit, idipsum bonum eligat pro iustitia talia sustinere; si autem viderit iniquitatem esse pro qua patitur, se infructuosissime laborare atque cruciari considerans, mutet in melius voluntatem, simulque careat et molestia sterili et ipsa iniquitate, multo utique gravius et perniciosius nocitura. Et vos cum aliquid adversus vos reges constituunt, admoneri vos credite, ut cogitetis quare ista patiamini; si propter iustitiam, revera illi persecutores vestri sunt; vos autem beati qui persecutionem passi propter iustitiam, possidebitis regnum coelorum [Mt 
V uvedenom texte stavia Augustín do jednej línie Božie pôsobenie na vôl'u s pôsobením pozemských vladárov. Nepriamo, cez tresty l'udských zákonodarcov, Boh privádza človeka k dobru. Augustín pripúšt'a možnost', že pozemské knieža môže niekedy vo zvrátenosti vlastnej vôle od dobra trestami aj odvracat', ale či už ide o spravodlivý alebo nespravodlivý trest, utrpenie s ním spojené nemá silu vnútorne človeka k niečomu zaviazat'. Ked’že vonkajšie zaväzovanie zákonom je slabšie než vnútorné zaväzovanie svedomím, ${ }^{14}$ človek je vonkajším trestom prinútený vo svetle vnútorného rozlišovania preverit', či trpí pre pravdu alebo pre mylný postoj. Vo svojom pohl'ade sa bud' utvrdí, a vtedy, súc prenasledovaný pre spravodlivost', môže dúfat' v prísl'ub Božieho král'ovstva (Mt 5,10), alebo objaví, že sa mýlil, a vtedy d'akuje Bohu i tým, ktorí naňho zoslali pozemský trest, že ho odvrátili od cesty vedúcej do záhuby.

Je táto logika zlučitel'ná s liberálnymi predpokladmi a ak nie, v čom sa líši? K otázke sa vyjadríme po tom, ako stručne priblížime jadro učenia o slobode jedného z predstavitel'ov klasického liberalizmu, Johna Stuarta Milla (1806-1873).

Základnú Millovu tézu možno vyjadritt tak, že každý dospelý jednotlivec má byt' ponechaný slobodne konat' to, čo považuje za dobro, pod podmienkou, že tým neškodí druhým. Z pohl'adu politického spoločenstva je právo človeka žit’ život na svoj vlastný spôsob najväčšou hodnotou, ktorú treba chránit'. Mill síce uznáva aj mravno-etický pohl'ad na spôsob existencie, ktorú si zvolil jednotlivec, teda skutočný, skúsenost'ou l'udstva overený rozdiel medzi dobrou a zlou životnou vol'bou, medzi cnost'ou a necnost'ou, ale tento pohl'ad v žiadnom prípade nemôže byt' kritériom, ktoré by spoločnost' oprávňovalo zasahovat’ do života jednotlivca donucovaním. Autonómia vol'by jednotlivca vyplýva z jeho jedinečnosti: „Ak človek disponuje priliehavou mierou zdravého rozumu a skúsenosti, jeho vlastný spôsob života je preňho najlepší - nie preto, že je najlepší sám osebe, ale preto, že je mu vlastný" (Mill 1995, 63). To, že sa osoba prejaví vo vol'be ako jedinečný subjekt, je

5, 10; 1 Pt 2, 20]; si autem propter iniquitatem schismatis vestri, quid illi nisi correctores vestri sunt; vos autem, sicut ceteri diversorum scelerum rei, qui poenas legibus pendunt, profecto infelices et in hoc saeculo et in futuro? Nemo ergo vobis aufert liberum arbitrium; sed vos diligenter attendite quid potius eligatis, utrum correcti vivere in pace, an in malitia perseverantes, falsi martyrii nomine vera supplicia sustinere. Sic vos autem alloquitur, quasi <indigna pro iustitia patiamini.Quasi> vero aliquid dignum vestra iniquitate patiamini, cum tanta indigna faciatis, et in tanta impunitate regnetis; ita furiosi, ut per Dei laudes amplius quam buccina bellica terreatis; ita calumniosi, ut etiam spontanea vestrorum praecipitia nostris persecutionibus imputetis" (Contra litt. Petil. 2,185).

${ }^{14}$ Ide tu o princíp primátu Božej autority pred nižšou, l'udskou autoritou, ktorý Augustín obrazne vyjadril nasledovne: „V obave, že sa previníš proti nadriadenému, skúmaj, či nad ním nestojí vyšší nadriadený a dbaj, aby si tohto neurazil (Qui enim times, ne offendas maiorem, vide ne forte sit maior isto, quem times offendere. Maiorem certe noli offendere)“ (Serm. 62, 8). 
väčšou hodnotou než to, či si zvolí najlepší spôsob života. Jeho okolie môže nanajvýš vyjadrit' svoj nesúhlas s jeho vol'bou, a to radami, pokynmi, presviedčaním alebo vyhýbaním sa mu; nesmie ho však nútit’. „Všetky chyby, ktorých sa [jednotlivec] pravdepodobne dopustí napriek radám a výstrahám, d'aleko prevyšujú zlo spočívajúce v tom, že sa iným dovolilo nútit’ ho do niečoho, čo oni považujú za jeho dobro" (Mill 1995, 71-72). Donucovanie trestami spadá pod kompetenciu zákonnej autority v tých prípadoch, kedy jednotlivec svojím správaním citel'ne škodí spoločenstvu, teda zasahuje do slobody a autonómie druhých.

Augustínovo a Millovo stanovisko sa v niečom podobajú a v niečom rozchádzajú. Obaja uznávajú slobodu svedomia, obaja (v rôznych okolnostiach) pripúšt'ajú i istú formu morálneho nátlaku a fyzického donucovania a obaja uprednostňujú nenásilné formy riešenia konfliktov medzi individuálnou vol'bou jednotlivca a spoločenským záujmom. Základný rozdiel je však v chápaní slobody. Podl'a Augustína t'ažko hovorit' o slobode rozhodovania tam, kde je človek vnútorne donucovaný otročením svojim vášňam a zarytým zvykom. Až vtedy sa môže slobodne rozhodnút', ked' sa odtrhne od tohto nereflektovaného donucovania, o ktorom si myslí, že je to jeho vol'ba. Je takpovediac povinnost'ou krest’anskej lásky slovne presviedčat' tých, ktorí v stave omylu spôsobujú škodu sebe i celému spoločenstvu. Ked' veci dospejú tak d'aleko, že vzniknuté napätie medzi občanmi prerastie do otvoreného konfliktu a násilností, štátna moc musí zasiahnut' i tvrdšími postihmi, aby bol nastolený poriadok, a aby previnilci rozpoznali nenáležitý stav svojho vnútra.

Ani Mill si nerobí ilúzie o stave slobody l'udstva a podobne ako Augustín súdi, že „despotizmus návykov je prekážkou l'udského rozvoja“ (Mill 1995, 65). Na rozdiel od hipponského biskupa však nepovažuje donucovanie za podmienku budúceho zdokonalenia. Problém vidí skôr v tom, že zákon a strach zo sankcie, ktorý formuje i verejnú mienku, robí z l'udí otrokov a odčerpáva silu ich vlastnej originalite a individualite. Preto najlepšou cestou, ako jednotlivcovi umožnit' konat' slobodne, je podl'a neho garantovanie toho, že za svoju vol'bu nebude postihnutý, ak sa bude držat' v medziach nehatenia slobody iných, ako sú stanovené zákonom.

Bolo by však mylné domnievat' sa, že Augustín chce "nasilu“ priviest' niekoho k správnej vol'be. Augustín dobre vie, že vol'ba, vychádzajúca z motívu vyhnút' sa trestu, pred Bohom neobstojí. Ide mu skôr o to, aby sa človek rozhodol slobodne, čo nie je možné, ak je vnútorne zviazaný a neslobodný, hoci by mu bola spoločensky garantovaná sloboda. Morálny a v krajnom prípade vážnych narušení spoločenského poriadku aj fyzický nátlak teda slúžia tomu, aby sa človek vo svojej híbke (privátna sféra) skutočne rozhodol pre dobro, ako ho osobne a reflektovane pochopil. Mill by zrejme takýto pohl'ad považoval za akýsi paternalizmus, ktorý prislúcha veku detstva a dospievania, ale nie veku dospelosti. Vyššie bolo povedané, že ak človek disponuje „priliehavou mierou zdravého rozumu a skúsenosti“, treba jeho vol'bu chránit' preto, že je jeho, teda odhliadnuc od toho, čo je jej 
substanciálnym obsahom, i od toho, či ju človek vykonal vo vnútornej slobode. Rozlíšenie medzi slobodou vol'by, ktorá zdegraduje na sledovanie spoločenských zvyklostí, a tou, ktorá reflektuje požiadavky racionality, je aj podl'a Milla morálne významné, ale z politicko-spoločenského hl'adiska, o ktoré mu ide, irelevantné. To znamená, že zákon nesmie skúmat' vnútorný kvalitatívny rozmer vol'by, ale len garantovat' slobodu vol'by, nech pochádza z akéhokol'vek prameňa. Je to podl'a Milla jediná možnost', ako umožnit' skutočný rozvoj individuality. Dá sa teda povedat', že kým pre Augustína sa človek k svojmu dobru (spása) dopracúva aj vd'aka istému (prechodnému) obmedzeniu jeho negatívnej slobody, teda slobody od donucovania zo strany moci, podl'a Milla sa človek k svojmu dobru (slobodný rozvoj individuality) dopracúva len pod podmienkou, že mu túto slobodu zákony garantujú. Vidíme tu teda zámenu, ktorá nastala $v$ tom, čo sa považuje za relatívne a čo za absolútne: spoločenské hl'adisko je u Augustína prekročené náboženským horizontom spásy, a preto, spolu so slobodou, ktorá je v jeho teologicky fundovanom názore i tak poplatná zvykom a vášňam, relativizované; naopak, u Milla je relativizované dobro, ktoré každej povahe a individualite vyhovuje iné, kým absolutizované je zákonné garantovanie slobody, lebo jedine ono zaručuje možnost' plurality životných volieb neopakovatel'ných jednotlivcov.

Ani Augustínova ani Millova argumentácia sa nevyhla istým jednostrannostiam. Problém Augustínovho poňatia vidíme v tom, že teologickú interpretáciu l'udskej prirodzenosti (padnutá a sama od seba neschopná dobra) povýšil do roviny spoločenského konceptu, čím vlastne otvoril cestu pre zdôvodnenie spoločensky uplatňovaného násilia, hoci sa snažil ospravedlnit' ju skutočným dobrom človeka. Na pomery a podmienky, v ktorých žil a pôsobil, však aj toto znamenalo posun. ${ }^{15}$ Pre Milla niet jedného skutočného dobra človeka, ktoré by zodpovedalo a vyhovovalo všetkým jednotlivcom. Ak napriek tomu treba stanovit' ciel', je ním slobodný rozvoj individuality. Absolútna spoločenská garancia tohto dobra však nakoniec môže viest' $\mathrm{k}$ tomu, že sa dobrota vol'by bude i v individuálnom hodnotení subjektu odvíjat' väčšmi od toho, že je jeho vlastnou vol'bou (tým samým sa stáva dobrou), než od toho, že je podl'a „zdravého rozumu a skúsenosti“, za čo je zodpovedný každý len sám pred sebou.

\section{Záver}

V príspevku sme sa snažili predostriet' Augustínove dôvody, ktoré stáli za zmenou jeho pohl'adu na štátne prenasledovanie donatistov. Augustín svoj súhlas

\footnotetext{
15 Podl'a P. Browna bolo donucovanie v istej forme jedným $\mathrm{z}$ „faktov života“ provinčného biskupa. Viacerí príslušníci kléru, zväčša pochádzajúci z vyšších tried militantnej kultúry, považovali donucovanie za bežný, morálne neproblematický prostriedok štrukturovania medzil'udských vzt’ahov, čím sa mal zabezpečovat' poriadok (Brown 1967, 107).
} 
s použitím násilných metód založil na pozitívnej skúsenosti s tým, že nátlak, ak sleduje pravdu a ak zlyhali nenásilné metódy, pomohol mnohým donatistom vrátit' sa k jednote a dokonca prejavit' vd'ačnost' za uplatnenie zákonnej sankcie. Nátlak v jeho ponímaní nemal nahradit' vieru, ale bol mienený ako prostriedok pomáhajúci prekonat' neuváženú zotrvačnost' v starých pozíciách. Dobro, ktoré sa nátlakom získava, je omnoho väčšie než zlo a utrpenie vyplývajúce z nátlaku. Donucovanie bolo z jeho strany, zdá sa v úprimnom presvedčení, chápané ako prostriedok krest'anskej lásky voči tým, ktorí vieru prijali a blúdia v nej, a ako také smelo byt' použité, až ked' zlyhali iné spôsoby (najmä vecná argumentácia, bratský dialóg). Každý nátlak musí byt' motivovaný skutočným záujmom o dobro (spásu) brata.

Následne sme priblížili dve otvorené otázky súčasnej diskusie o tomto Augustínovom postoji. Prvou bola otázka, či je možné politicky podporovat' finálny ciel' spásu človeka a súčasne zastávat' pohl’ad, podl'a ktorého sa štát ako pozemské spoločenstvo stará o svetské ciele. Priklonili sme sa k názoru, že hipponský biskup napriek principiálnemu oddeleniu pozemskej a Božej obce ako dvoch eschatologických spoločenstiev predsa túžil po priblížení pozemskej civitas tej Božej. To znamená, že krest'anskí vladári nemohli slúžit' svojim záujmom a zvel'ad'ovaniu svojej slávy, ale Božím ciel’om, avšak vždy iba spôsobom, ktorý zodpovedá krest'anskej láske. Druhou bola otázka, či je naznačený Augustínov postoj v súlade so súčasným chápaním slobody. Tu sme sa dopracovali k záveru, že pre liberálne poňatie, podl'a ktorého je sloboda najvyššou politickou hodnotou, je Augustínov náboženský postoj, ktorý slobodu nazerá vo funkcii spoločného ciel'a (spása), neprijatel'ný.

\section{Literatúra}

ANDOKOVÁ, M. (2013): Rečnícke umenie sv. Augustína v kázňach k stupňovým žalmom. Bratislava: Iris.

AURELIUS AUGUSTINUS: Contra litteras Petiliani donatistae libri tres. (PL 43) [skratka Contra litt. Petil.] In: S. Aurelii Augustini Opera omnia - editio latina. Web. 15.09.2015. http://www.augustinus.it/latino/contro_petiliano/index.htm AURELIUS AUGUSTINUS: Contra Cresconium Grammaticum Donatistam libri quatuor. (PL 43) [skratka Contra Cresc.] In: S. Aurelii Augustini Opera omnia - editio latina. Web. 15.09.2015.

http://www.augustinus.it/latino/contro_cresconio/index.htm

AURELIUS AUGUSTINUS: De patientia liber unus. (PL 40) [skratka De patientia] In: Nuova Biblioteca Agostiniana. Web. 15.09.2015. http://www.augustinus.it/latino/pazienza/index.htm 
AURELIUS AUGUSTINUS: De Civitate Dei contra paganos libri XXII. (PL 41) [skratka De civ. Dei] In: Nuova Biblioteca Agostiniana. Web. 15.09.2015. http://www.augustinus.it/latino/cdd/index.htm

AURELIUS AUGUSTINUS: Epistolae. (PL 33) [skratka Ep.] In: S. Aurelii Augustini Opera omnia - editio latina. Web. 15.09.2015.

http://www.augustinus.it/latino/lettere/index.htm

AURELIUS AUGUSTINUS: In Epistolam Ioannis ad Parthos tractatus decem (PL 35) [skratka In Ep. Io. tr.] In: S. Aurelii Augustini Opera omnia - editio latina. Web. 15.09.2015. http://www.augustinus.it/latino/commento_lsg/index2.htm AURELIUS AUGUSTINUS: Sermones (PL 38) [skratka Serm.] In: S. Aurelii Augustini Opera omnia - editio latina. Web. 15. Sep. 2015. http://www.augustinus.it/latino/discorsi/index2.htm AURELIUS AUGUSTINUS (2000): Augustin Marcellinovi. In: HOŠEK, R. (ed.): Aurelius Augustinus : Říman • člověk · světec. Praha: Vyšehrad, 306-308.

BONNER, G. (2008): Schisma a jednota Církve. In: Hazlett, I. (ed.): Rané krest'anství: počátky a vývoj církve do roku 600. Brno: Centrum pro studium demokracie a kultury (CDK), 201-210.

BOWLIN, J. R. (1997): Augustine on Justifying Coercion. Annual of the Society of Christian Ethics, 17, 49-70.

BROWN, P. (1964): St. Augustine's Attitude to Religious Coercion. The Journal of Roman Studies, 54 (1-2), 107-116.

GARBARINO, C. (2011): Augustine, Donatists and Martyrdom. In: Sarris, P. - Dal Santo, M. - Booth, Ph. (eds.): An Age of Saints? Power, Conflict and Dissent in Early Medieval Christianity. Leiden, The Netherlands: Brill, 49-61.

KARFÍKOVÁ, L. (2011): Augustin a jeho dvojí vklad do dějin politického myšlení. In: Herold, V. - Müller, I. - Havlíček, A. (eds): Dějiny politického myšlení II/1. Politické myšlení raného krest'anství a středověku. Praha: Oikoymenh, 74-122. LICHNER, M. (2014): Alegorická a typologická exegéza v službe Augustínovej obhajoby práva hriešnika zostat' v Cirkvi. In: Nové horizonty, VIII (3), 139-145. LICHNER, M. (2014): Vers une ecclésiologie de la tolerantia : recherche sur Saint Augustin. Budapest: L'Harmattan Kiadó/Sapientia Szerzetesi Hittudományi Föiskola.

MARKUS, R. A. (2002): Marius Victorinus a Augustin. In: Armstrong, A. H. (ed.): Filosofie pozdní antiky. Praha: Oikoymenh, 371-469.

MILL, J. S. (1995): O slobode. Preložil E. Višňovský. Bratislava: Iris.

OPTATUS AFRUS: De Schismate Donatistarum Adversus Parmenianum. [skratka Adv. Parm.] Web. 20.11.2015. http://www.documentacatholicaomnia.eu/ 02m/0323-0387,_Optatus_Afrus,_De_Schismate_Donatistarum_Adversus_ Parmenianum,_MLT.pdf

ROHR, J. (1967): Religious Toleration in St. Augustine. Journal of Church and State, $9(1), 51-70$. 
Augustínov postoj v kauze prenasledovania donatistov: Dve otvorené otázky

SMITHER, E. L. (2006): Persuasion or Coercion: Augustine on the State's Role in Dealing with Other Religions and Heresies. Faculty Publications and Presentations. Paper 14. Web. 15.09.2015.

http://digitalcommons.liberty.edu/lts_fac_pubs/14

SPANNEUT, M. (1990): Saint Augustin et la violence. In: Studia Moralia, 28, 79113.

VAŠEK, M. (2007): Aurelius Augustinus. O vôli, milosti a predurčení. Bratislava: Iris.

Príspevok vznikol na Katedre náboženských štúdií Filozofickej fakulty Univerzity Konštantína Filozofa v Nitre ako súčast' riešenia grantovej úlohy VEGA č. 1/0888/16 Spory o etickú neutralitu štátu a konflikty tolerancie v modernej pluralitnej spoločnosti.

doc. Mgr. Andrea Blaščíková, PhD.

Univerzita Konštantína Filozofa v Nitre

Filozofická fakulta

Katedra náboženských štúdií

Hodžova 1

94974 Nitra

Slovenská republika

ablascikova@ukf.sk 